\title{
Impact of Agricultural Output Volatility on Economic Growth in Nigeria: Egarch Analysis
}

\author{
Ogunbadejo Hussain Kehinde \& Oladipo Agnes.E \\ Nigerian institute for oceanography \& marine research Vitoria Island Lagos.
}

\begin{abstract}
This study investigated the impact of agriculture output volatility on economic growth in Nigeria using time series data from 1970 - 2013. It employed the ordinary least square technique and Exponential generalized Autoregressive conditional hetroscedasticity (EQARCH) analysis. Generalized Autoregressive conditional Hetroscedasticity (GARCH) model has been applied in this study to calculate volatility of agriculture output. Augmented dickey fuller is applied for unit root test while the Eigen value test are used to capture the long term effect of there variables on economic performance.The result revealed that agriculture output and labour force have a positive impact on economic growth though not statistically significant. While agriculture output volatility have a negative impact on growth.The study recommends the policies which would focus on stability of the economy also government should provide adequate infrastructure and policy that will be conducive for increase in agriculture output.
\end{abstract}

Keywords: Output volatility, Economic growth, GARCH, \& EGARCH.

\section{Introduction}

For many developing countries, agriculture is the largest sector in terms of its share in the nation's total Gross Domestic Product (GDP) and employment (Fan et al., 2008; Fan et al., 2009). More importantly, majority of the world's poor live in rural areas and depends upon agriculture for their livelihood (Binswanger and Townsend, 2000). Hence, agriculture is critical for both economic development and poverty reduction (Armas $e t$ al., 2012). The rising commodity prices and volatility in 2008 and subsequent concerns about food security have served as a wake-up call to reconsider the food system and foster agricultural development.

These concerns are fueled by long term projections of increasing demand for agricultural commodities due to population growth, long life expectancy, rapid economic growth, increased purchasing powers and changing consumption patterns in emerging economies, land degradation due to intensive production and adverse climate change impacts, and increased demand for nonfood crops and bio-fuels due to recent bio-fuels initiatives and legislation ( Hallam 2009: 2, Miller et al. 2010, UNCTAD 2009: 93, McNellis 2009: 1). The agricultural sector has long been neglected as motor of development and poverty reduction, and a lack of private and public investment has led to lower productivity growth rates and stagnate production in many developing countries. To achieve food supply for a potential world population of 9.1 billion in 2050, USD 83 billion per annum should be invested in the agricultural sector of developing countries (FAO 2009a, b). Most of the investment is expected to come from farmers themselves, but also from the public sector providing infrastructure, institutions, and Research Development.

Public investment is found to be most effective to ensure food security and poverty reduction in agriculture, but might not be able to meet these investment needs. Agriculture volatility affects economic growth through two channels. First, high volatility means more investment risk in agriculture sector, which tends to discourage investment in agriculture sector and there by there is slowdown in economic growth. Secondly, high volatility also means more income risk, which tends to raise precautionary savings, which in turn encourages investment in agriculture sector and it boosts economic growth. Agriculture is the major foundation of boosting economic growth in Nigeria. Agriculture's traditional roles are: to provide food, create jobs, earn export income, generate savings and funds for investment, and produce primary commodities for expanding industries. So through different ways agriculture sector is contributing in economic growth.Agriculture directly and indirectly is the biggest source of employment for the people of Nigeria. Employment leads towards higher per capita income of people and increase the GDP of Nigeria. High per capita income results in improved standard of living of the people which mean more access to basic needs, better health facilities, quality education etc, which are all the signs of economic development. In this way employment as a result of agricultural activity is adding momentum to the economic growth of Nigeria.

\section{Literature Review}

Agriculture usually plays a vital role in the economy of every nation that exists. Not only for the reason that it tends to feed the entire population of a country but also in the respect that agriculture correlates and interacts with all the related industries of that country. A country is usually considered to be a social and 
politically stable nation if it possesses a very stable agricultural basis. Volatility is a hurdle in achieving sustained economic growth which is an important objective of any economy. The pattern of economic volatility in Pakistan is complex and there is no sufficient literature exists to investigate the agriculture volatility. In terms GDP the most volatile sectors are agricultural, industrial and service; while the least volatile are distribution, transport, and communications. Ghosh, Nilabja et al (2009) examined whether trade liberalization has indeed worse off the unexpected volatilities of agricultural (producer) prices in India and if so, what could be sources to get rid of that situation. They used ARCH and the GARCH models and their modified versions on annual data on agricultural prices for the sample period of 31 years (1975-76 to 2005-06) to examine the effect of trade liberalization on price volatility. Their findings show that in the case of prices, the trade liberalization period has seen an increase in the volatility of production in the cases of cotton and groundnut while the other food grain crops became more stable. It shows that trade liberalization have fruitful effect on food security and food management.

Fiaschi, Davide et al (2005) identified the main determinants of growth volatility of a country. They proposed a model to explain the growth rate volatility through structural change and the economy size. They used nonparametric techniques for testing. Their results show that growth volatility is negatively related to total GDP, proxy for the dimension of the economy, when there is economic integration in the world markets and in isolation its impact is ambiguous. Furthermore, growth volatility is negatively related to the share of agriculture on GDP, proxy for structural change.Iwai, Nobuyuki et al (2003) tried to sort out the effect of economic integration on economic growth. Their objective was to provide an alternative path for economic growth through economic integration among LDCs. They developed a simple endogenous growth model with two sources of production shocks (agriculture and manufacturing). Their study results show that economic integration is welfare improving if it reduces production volatility. Awokuse (2009) tried to bridge the gap by re-examining the relationship between agriculture and economic growth by applying recent advances in time series analysis to national data from a different group of fifteen developing and transition economies in Africa, Asia and Latin America. His basic model was an extension of the neoclassical growth model who consider agriculture sector as a major contributor to economic growth. He used autoregressive distributed lag (ARDL) error correction modeling approach to find out the short-run and long-run relationships between both. The results of his study show that agriculture and economic growth both have strong relationship and agriculture is an engine of economic growth. Further the results show that trade openness also contributes in GDP growth. Anthony (2010) presented an empirical analysis of the impact of agriculture credit on economic growth or the contribution of agriculture to GDP in Nigeria. In order to examine this impact, he specified a functional and operational form, and established a causal relationship between GDP and agricultural variables. His study findings revealed that agricultural variables have significant impact on economic growth and export growth. Matsuyama (1996) empirically tested the impact of agricultural productivity on the long-run economic growth of the contemporary developing countries. He used Ordinary Least Squares (OLS) and panel data regression Techniques. The theory predicted that the openness of economies negatively affects the gains in the economic growth with the improvement in the agricultural productivity; however, this effect is not strong enough to cause either a long-run negative relationship between economic growth and agricultural productivity.

Hye, Adnan et al (2010) analyzed the role of agricultural product prices and government expenditure in the determination of agricultural performance in the case of Pakistan. Dickey Fuller Generalized Least Square (DF-GLS) unit root test is used in order to determine the level of integration and autoregressive distributed lag model (ARDL) was also used. Results show that in the long run the government expenditures on agriculture and agricultural prices are positively (statistically significant) shock on agricultural performance.Meijerink, Gerdien et al (2007) in their paper studied the agriculture contribution in economic development, and particular relate it to poverty. They also checked the relationship between economic or agricultural growth and pro-poor development. Agricultural development is indeed important to economic development, then why, despite all the efforts and investments, has this not led to more successes? Today most of the observers agreed on that the Agri. sector contributes in economic growth but that economic growth reduces the agriculture role in terms of GDP. Now they realized its importance and linkage with the other sectors. They stress on the need to eliminate poverty through different programs that target poor population of the rural areas. The direct role of the agri. sector is provision of food, employment, foreign exchange through exports and raw material for the industries. Along this agriculture sector plays also an important role indirectly e.g. environmental services. A review of 11 case-studies by FAO revealed that these indirect contributions of agri. sector seldom reflected in the policy formulations.Hamid, Naved et al (1990) examined the role of public investment in determining the patterns of agriculture development in Pakistan. Physical and institutional infrastructure supports agriculture, and investments in these leads to the country's economic development. Agriculture development depend on the degree to which education can be improved, organized network, knowledge communicated and social relations at the village level harmonized. Due to agriculture development there would be economic development. 
World Bank (2008) published a most influential report called World Development Report. According to this report growth in the agricultural sector contributes proportionally more in poverty reduction as compared to growth in any other economic sector. So there should be more concentration on agriculture sector in order to achieving MDG's first goal, poverty reduction.Hussain, Turab et al (1997) examined the relationship between aggregate agricultural productivity and poverty in Pakistan through the course of time and along with estimated the determinants of agri. sector production. For the estimation they used Ordinary Least Squares (OLS) method. Their study findings shows that increase in agricultural sector production alleviate poverty in Pakistan but not at that rate at which population is increasing. In the case of the determinants of agricultural productivity, their study results shows that use of fertilizers played an important role increasing Agriculture production in Pakistan especially in late sixties with the beginning of Green Revolution.

Akram, Waqar et al (2006) estimated the long term impact of agriculture credit on growth and poverty in Pakistan through Cointegration and Error Correction Models (ECM) covering the period from 1973 to 2005. They used Gross Domestic Product (GDP), Agricultural GDP, Water Availability, Agricultural Credit, and Number of Tube wells, Number of Tractors, Fertilizer, Seed, Poverty and Rural Poverty variables in their study. Their study results show that the water availability agricultural credit, fertilizer, seed, and tractors have a significant impact in reducing poverty.

\section{Objectives}

To determine the magnitude of agricultural output in Nigeria from 1970-2013

To establish the effects of agricultural output volatility on economic growth

Policy implications of the findings

\section{Methodology and Data:}

The variables we used in this paper are gross domestic product (GDP), Agriculture Volatility (VOLT), agricultural production (AGR), Agricultural employment (EMP). The main objective of this study is to use time series data from 1970-2013 to analyze the actual cause of the agricultural volatility and its impact on the economic growth of the Nigeria.Until a decade ago the focus of most macro econometric and financial time series modeling was on the worldly higher order moments in different sectors. Risk and uncertainty elements increased the importance of measuring volatility in modern economic theory. The development of new econometric time series techniques allow for the modeling of time varying variances and covariance. Econometricians are being asked to forecast and analyze the size of the errors of the model. In this case of volatility, the standard tools are: Auto Regressive Conditional Heteroscadesticity (ARCH) model introduced by Professor Engle (1982) that explained time varying volatility using ARCH and GARCH Models for which he won the Nobel Prize in 2003 and Generalized Auto Regressive Conditional Heteroscadesticity (GARCH) introduced by Bollerslev (1986). ARCH models are employed commonly in modeling financial time series that exhibit time-varying volatility clustering, i.e. periods of swings followed by periods of relative calm. Although the GARCH methodology has been used extensively in modeling financial time series and in particular for stock returns, a detailed study of the application of the GARCH methodology on intraday returns of individual stocks have only been published very recently by Rahman, et al (2002). So we measured the agriculture volatility by using Auto Regressive Conditional Heteroscadesticity (ARCH) and Generalized Auto Regressive Conditional Heteroscadesticity (GARCH) econometrics techniques.

\section{Model Specification}

This study adopted EGARCH methodology to model agricultural output volatility. EGARCH model is an improvement of autoregressive conditional heteroskedasticity (ARCH) model proposed by Engle (1982) and generalized autoregressive conditional heteroskedasticity (GARCH) by Bollersley (1986) and Taylor (1986).

First volatility measures ofAGR output was obtained by regressing AGRGDP on its one year lagged values, with intercept and linear time (Trend) terms.

\section{AGRGDPt $=\beta 0+\beta 1$ AGRGDPt-1 + $\beta 2$ Trend $+\mu t \quad$ (1)}

Where $\boldsymbol{\mu t}$ is the error term and from which standard deviation will be calculated

AGRGDPt $=\mathbf{m}+\boldsymbol{\delta A G R G D P t}-1+\mathbf{U}^{\mathbf{t}}+\phi \mathbf{U}_{\mathrm{t}-1}$

Where $U^{\prime \prime}$ has a mean and a conditional variance of zero and $\delta^{2} \mathrm{t}$ respectively, $\mathrm{m}$ is the intercept term, $\delta$ and $\phi$ represent the magnitude of the autoregressive term and moving average terms respectively and;

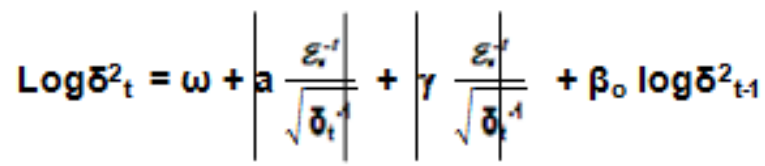


Where $\delta_{\mathrm{t}-1}^{2}$ represents conditional variance of Üt, a, $\beta$ o and $\gamma$ are the parameters of ARCH, GARCH and leverage parameters respectively. Thus the log transformation of the variance rules out the negative variances. Therefore no restriction is required on the variance equation to ensure a positive volatility process as in the GARCH model. Once the study identifies the magnitude of volatility, the study was to establish the effects of agricultural output volatility on economic growth using ARDL approach to cointegration also known as bounds testing approach. The ARDL was developed by Pesaran et al. (2001) as an alternative procedure to the standard cointegration analysis. The equation to be estimated was specified as:

\section{GDPt $=\beta 0+\beta 1$ VOLT $+\beta 2$ AGRI $+\beta 3$ EMPL $+\mu t$}

The sample period covers the annual data from 1972-2011 and will be obtained from World Bank (WB) and National Bureau of Statistics. After collection of data on above stated variables, different time series econometrics techniques have been used for the analysis of study objectives.

\section{Estimation Techniques}

In the first step we applied the Augmented Dickey Fuller (ADF) to verify the presence of unit root in the series which is an extended version of the Dickey Fuller (DF) test because DF is only valid for AR (1) process not for others, so due to this drawback Dickey and Fuller (1979) introduced ADF test which includes lagged terms of the dependent variable in order to remove autocorrelation. The ARCH model is further extend by Engle and Bollerslev (1986) commonly known as (GARCH), which includes the lagged values of the conditional variance. The $(\mathrm{GARCH})$ model is therefore capable of taking the leptokurtosis, skewness, and volatility clustering in data time series. GARCH model also takes into account the historical variances which explain the future variances. Therefore, when there is a Heteroskedasticity in the data, it means that the expected value of the error term is not constant. Models of stochastic volatility and ARCH/GARCH are of significance importance in forecasting volatility, because they explain the importance of the degree persistence of shocks in the volatility in returns and different macroeconomic variables. The entire focus in the use of ARCH/GARCH is on the error process.

\section{Empirical Estimation and Results}

Descriptive Statistics The most common measures are mean, median, skeweness and kurtosis.In a normally distributed data, the mean and the median should be equal, from the variables in this study the mean and the medians of lngdp, lnagric, lnvol are almost equal, they are normally distributed. Meanwhile the mean and median of lnemp are not the same, that is, theyare not normally distributed. The standard deviation of agricultural output (AGR) is 3.555, which will represent (AGR) volatility in this study. Skewedness is the point in the distribution which should be within the range of -2 and +2 for normally distribution. For a normal distribution skewdness is zero Since all the variables are within the range they are normally distributed. Kurtosis is the peakedness of a distribution and should be within -3 and +3 range when the data is normally distributed. Kurtosis is a measure of how outlier-prone a distribution is. Kurtosis for a normal distribution is 3 . The variables has kurtosis greater than 3 meaning that the data are less outlier prone,that is ,it is not normally distributed.

Table 1: Descriptive Statistics

\begin{tabular}{|l|l|l|l|l|}
\hline & LNGDP & LNAGR & LNEMP & LNVO \\
\hline Mean & 12.71178 & 11.61442 & 14.77981 & -8.192523 \\
\hline Median & 12.50414 & 11.38985 & 17.18791 & -8.287067 \\
\hline Maximum & 24.47034 & 23.41173 & 18.09903 & 0.000000 \\
\hline Minimum & 8.347353 & 7.500364 & 9.370075 & -14.52126 \\
\hline Std. Dev. & 3.519679 & 3.554507 & 3.483509 & 2.235415 \\
\hline Skewness & 2.368841 & 2.280746 & -0.522720 & 0.923959 \\
\hline Kurtosis & 8.970288 & 8.586581 & 1.437012 & 7.178926 \\
\hline Jarque-Bera & 106.4983 & 95.36466 & 6.482444 & 38.27674 \\
\hline Probability & 0.000000 & 0.000000 & 0.039116 & 0.000000 \\
\hline Sum & 559.3182 & 511.0347 & 650.3116 & -360.4710 \\
\hline Sum Sq. Dev. & 532.6900 & 543.2844 & 521.7979 & 214.8744 \\
\hline Observations & 44 & 44 & 44 & 44 \\
\hline
\end{tabular}

The Jarque-Bera (JB) statistics test is used to test for normality of the series. It measures the difference of the skewness and kurtosis of a series from those of a normal distribution. The null hypothesis (H0) is that residuals are normally distributed, therefore reject $\mathrm{H} 0$ if $\mathrm{JB}>\chi^{2}(2)$ or if $\mathrm{p}<0.05$.

\section{The Magnitude of AGR Volatility}

The magnitude of AGR was determined by the standard deviation of Agricultural output volatility and the magnitude is 3.520 as shown in table 2 
Table 2: ARCH family regression

\begin{tabular}{|l|l|l|l|l|l|l|}
\hline variable & coef & Std error & $\mathrm{Z}$ & $\mathrm{p}>\mathrm{z}$ & low & high \\
\hline Lnagr & 1.0127 & 0.00895 & 113.056 & 0.000 & 0.9945 & 1.0309 \\
\hline arch & 0.0147 & 0.37440 & 0.03913 & 0.9688 & 0.1554 & 1.5806 \\
\hline garch & 0.8680 & 0.35134 & 2.4705 & 0.0135 & -0.1552 & 0.1854 \\
\hline egarch & 0.0151 & 0.08399 & 0.1798 & 0.8573 & $5.2 \mathrm{E}+296$ & $5.2 \mathrm{E}+296$ \\
\hline c & 0.00473 & 0.001918 & 0.2466 & 0.8052 & -0.7447 & 0.7740 \\
\hline
\end{tabular}

From the above results the coefficients $0.0147,0.8680,0.0151$ are the arch, garch, and the egarch parameters respectively.



The $\mathrm{a}=0.0147$ parameter represents a magnitude effect of the model. $\beta \mathrm{o}=0.8680$ Measures the persistence in conditional volatility and if it is relatively large, then volatility takes a long time to clear out following a crisis in the market. Since it is relatively small, it implies that conditional volatility does not take a long time to clear. Therefore AGR volatility does not take a long time to clear. The parameter $\gamma=0.0151$ measures the leverage effect, and since its $\gamma>0$, it implies that negative shocks (bad news) generate high volatility than positive shocks (good news).

\section{Unit Root Test Results}

In order to investigate the stationary properties of the time series, the presence of unit root was tested. This was achieved by applying augment Dickey-Fuller (ADF) test. The null hypothesis of the unit root implies non-stationarity, such that if the null hypothesis is rejected then the series is stationary.

Table 3: Unit root test

\begin{tabular}{|l|l|l|l|l|}
\hline variable & Coef & $1 \%$ & Order of & Remarks \\
\hline lngdp & -6.4475 & -3.6010 & $1(1)$ & Stationary \\
\hline lnagr & -6.2553 & 3.6010 & $1(1)$ & Stationary \\
\hline lnemp & -7.0267 & 3.6056 & $1(1)$ & Stationary \\
\hline lnvol & -6.5405 & 3.5966 & $1(0)$ & Stationary \\
\hline
\end{tabular}

After establishing the order of integration of time series, cointegration test has to be done. Cointegration techniques are used to establish valid long-run relationship between variables. The Autoregressive Distributed Lag Bound test for cointegration was adopted in this study. Before conducting the bounds test, the order of integration for each variable was ascertained by Augmented Dickey-Fuller (ADF), as shown above. This was to ensure that the variables are not I (2) stationary, to avoid spurious results because the bounds test is based on the assumption that the variables are I (0) or I (1).

\section{Estimation Results}

Table 4 shows results of the long run estimate based on the Schwartz Bayesian criteria. The selected ARDL ( $1,1,1$, and 0$)$ passes the standard diagnostic tests. The results show that agricultural output affects positively (1.0184) and significant. This implies that agricultural output in Nigeria have a positive stimulating effect on economic growth . This may be due to fact that most economic activity in the country is related to agriculture

Table 4: Estimate of the long run coefficient ARDL

\begin{tabular}{|l|l|l|l|l|}
\hline Variable & Coefficient & Std. Error & t-Statistic & Prob. \\
\hline $\mathrm{C}$ & 0.026581 & 0.111644 & 0.238091 & 0.8132 \\
\hline $\mathrm{D}($ LNGDP(-1) $)$ & -1.094454 & 0.165474 & -6.614057 & 0.0000 \\
\hline $\mathrm{D}($ LNAGR, $)$ & 1.018421 & 0.013456 & 75.68501 & 0.0000 \\
\hline $\mathrm{D}($ LNAGR(-1) $)$ & 1.106469 & 0.168938 & 6.549548 & 0.0000 \\
\hline $\mathrm{D}($ LNEMP,2) & 0.008680 & 0.018861 & 0.460207 & 0.6482 \\
\hline $\mathrm{D}($ LNEMP(-1) $)$ & -0.015383 & 0.027199 & -0.565585 & 0.5753 \\
\hline LNVO & 0.002714 & 0.013014 & 0.208554 & 0.8360 \\
\hline
\end{tabular}

The equation above shows that agriculture volatility is negatively and non significantly impacting economic growth. Coefficient shows that a unit change in agriculture volatility cause to reduction 0.0027 in the economic growth of Nigeria. There is a scanty study available on agriculture volatility but Azid Toseef, Naeem Khaliq measured the volatility of different sectors and found negative link between volatility and economic growth. High volatility means more investment risk in agriculture sector, which tends to discourage investment 
in agriculture sector. The coefficient of employment was positive 0.00868 . This shows that as employment increases the economic growth also increases Agriculture sector directly and indirectly also a biggest source of employment for the people of Nigeria. Employment leads towards higher per capita income of people and increased Nigeria GDP of because high per capita income results in improved standard of living of the people which mean more access to basic needs, better health facilities, quality education etc, which are all the signs of economic development. In this way employment as a result of agricultural activity is adding momentum to the economic growth of Nigeria. From the equation it also indicate $1 \%$ change in agriculture employment lead to $0.65 \%$ change in the economic growth. Labor force participation in agri. sector is an important variable to determine agriculture performance; it causes to increase agriculture production and their income. It will lead to improve the living standard of labors that will boost up economic growth.

Table 5: Estimates of the Error Correction Model

\begin{tabular}{|l|l|l|l|l|}
\hline Variable & Coefficient & Std. Error & t-Statistic & Prob. \\
\hline C & -0.023681 & 0.102956 & -0.230016 & 0.8195 \\
\hline D(LNGDP(-1)) & -1.008768 & 0.153298 & -6.580449 & 0.0000 \\
\hline D(LNAGR,2) & 1.021330 & 0.012272 & 83.22351 & 0.0000 \\
\hline D(LNAGR(-1)) & 1.027928 & 0.155939 & 6.591859 & 0.0000 \\
\hline D(LNEMP,2) & 0.000936 & 0.017351 & 0.053944 & 0.9573 \\
\hline D(LNEMP(-1)) & -0.016956 & 0.024728 & -0.685695 & 0.4976 \\
\hline LNVO & -0.003252 & 0.012008 & -0.270861 & 0.7881 \\
\hline ECM(-1) & -0.314054 & 0.108596 & -2.891955 & 0.0066 \\
\hline R-squared & 0.998434 & Mean dependent var & -0.001585 \\
\hline Adjusted R-squared & 0.998111 & S.D. dependent var & 2.408518 \\
\hline S.E. of regression & 0.104674 & Akaike info criterion & -1.506285 \\
\hline Sum squared resid & 0.372527 & Schwarz criterion & -1.175301 \\
\hline Log likelihood & 39.63199 & Hannan-Quinn criter. & -1.384966 \\
\hline F-statistic & 3096.176 & \multicolumn{2}{|l|}{ Durbin-Watson stat } & 2.027277 \\
\hline Prob(F-statistic) & 0.000000 & \multicolumn{4}{l}{} \\
\hline
\end{tabular}

From the results presented in table 4.8 the coefficient of the error term ECM (-1) is negative and significant and this confirms the expected results from economic theory. The ECM (-1) coefficient of -0.314 is interpreted as speed of adjustment to the long run equilibrium. Therefore, this implies that approximately $31 \%$ of all the deviations in the past will be corrected (adjusted to the equilibrium) during the present period. The low value of the error term indicates that the economic agents remove a small percentage of disequilibrium in each period. The value of Durbin Watson test is 2.027277 which can be approximated to 2 meaning that there is no problem of serial correlation of the residuals. The value of $\mathrm{R}^{-2}$ is 0.9981 implying that approximately $99.81 \%$ of all the changes in the dependent variable are brought about by the changes in the explanatory variables

The coefficient of Agriculture output volatility was negative but statistically insignificant both in the short run and in the long run. Under the theoretical framework volatility increases the cost of innovation; therefore have negative effects on growth. This conforms to the findings of other studies (Alpasla 2011,chee-Keong \& Liew 2011, Dausa, 2007, Lensink \& Morrisey 2002). The coefficient of -0.0033 in the short run indicates that a $1 \%$ increase in foreign direct investment volatility will lead to decrease in real GDP growth rate by approximately $0.003 \%$ holding all other factors constant.

\section{Conclusion And Recommendations:}

This paper investigates the impact of agricultural output volatility on economic growth in Nigeria .The natural logarithm GDP were used as the dependent variable while agriculture output volatility, and labour force were used as the independent variables. The descriptive analysis indicates that all series are normallydistributed. The ADF test was used to check for unit root. The ADF test revealed that agriculture output volatility were stationary at levels, while agriculture output, and labour force were stationary at first differences.An error correction model (ECM) was used to estimate the empirical model.The findings show that agriculture output and labour force have a positive impact on economic growth though not statistically significant. While agriculture output volatility have a negative impact on growth. This study contributes to literature by not only establishing the effects of agriculture output on economic growth, but also by incorporating the effects of agriculture output volatility on economic growth.Policies which would focus on the enhancement of the internal economy, especially the stability of the economy, should be pursued by Nigerian government. More so, regulators can undertake sustainability impact assessment and regulate microeconomic and local condition. This includes monitoring of benchmarks and business practice, voluntary guidelines, and transfer of environmentally sound technology In the light of the above findings, the followings recommendation are proposed to encourage and improve agriculture output the in Nigeria: Government should provide adequate infrastructure and policy framework that will be conducive for increase in agriculture output . 


\section{References}

[1]. Akram, W., Hussain, Z., Sabir, H.M. Hussain (2008). Impact of Agricultural Credit on growth and poverty in Pakistan (Time Series Analysis). European Journal of Scientific Research, 23(2), 243-251.

[2]. Alpaslan, A 2011, Volatility of Foreign Direct Investment and Economic Growth: Empirical Evidence from the Czech Republic and Hungary. Besevler, Ankara, Turkey

[3]. Anthony, E. (2010). Agricultural Credit and Economic Growth in Nigeria: An Empirical Analysis: Economics Department, Ambrose Alli University Ekpoma, Nigeria.

[4]. Armas, E.B., C.G. Osorio, B. Moreno-Dodson and D.E. Abriningrum, (2012). Agriculture Public Spending and Growth in Indonesia. The World Bank, East Asia Region, Poverty Reduction and Economic Management Unit. Policy Research Working Paper No. 5977.

[5]. Awokuse, O. T. (2009). Does Agriculture Really Matters for Economic Growth in Developing Countries? : Department of Food \& Resource Economics University of Delaware Newark, DE 19717, USA.

[6]. Azid, T., Khaliq, N., \& Jamil, M. (n.d.). Sectoral Volatility, Development and Governance: A case study of Pakistan.

[7]. Binswanger, H.P. and R.T. Townsend,( 2000). The growth performance of agriculture in Sub-Saharan Africa. Am. J. Agric. Econ., 82(5): 1075-1086.

[8]. Bollerslev, T 1986, 'Generalized Autoregressive Conditional Heteroskedasticity,' Journal of Econometrics, Vol.31 no. 3, pp 307-27

[9]. Choong, C-K \& Liew, V.K-S 2011, 'Impact of Foreign Direct Investment Volatility on Economic Growth of five Asean Countries, Economics Journal , Vol. 29 no. 3, pp 1829-1841

[10]. Duasa, J 2007, 'Malaysian FDI and Growth: Does stability matter?' Journal of economic Cooperation , Vol. 28 no. 2, pp 83-98

[11]. Engle, RF \& Granger, G 1987, 'Co-integration and Error Correction Representation, Estimation and Testing,' Journal of Econometrics, Vol. 55, pp 251-76

[12]. Fan S, Mogues T, Benin S (2009). Setting Priorities for Public Spending for Agricultural and Rural Development in Africa.” IFPRI Policy Brief 12, April, International Food Policy Research Institute (IFPRI). pp. 23 - 34 FAO (2009a). How to feed the world in 2050 .

[13]. FAO (2009b). Investment. Brief. http://www.fao. org/fileadmin/templates/wsfs/ docs/Issues_papers/ HLEF2050_ Investment.pdf, last accessed June

[14]. Fiaschi, D., \& Lavezzi, M. A. (2005). On the Determinants of Growth Volatility: A Nonparametric Approach:University of Pisa Dipartimento di Scienze Economiche.

[15]. Ghosh, N., \& Chakravarty S. (2009). Effect of Trade liberalization on Volatility: The Experience of Indian Agriculture: Fourth Annual International Conference on Public Policy and Management Indian Institute of Management Bangalore (IIMB) 9-12 August 2009.

[16]. Hallam D (2009). Foreign investment in developing country agriculture - Issues, policy implications and international response. Conference documentation of VIII Global Forum on International Investment, OECD.

[17]. Hamid, N., \& Wouter, T. (n.d.) Agricultural growth and Economic Development: the case of Pakistan: OECD development centre Working Paper No. 13

[18]. Hussain, T. M. S., \& Ishfaq, M. (1997). Dynamics of agricultural productivity and poverty in Pakistan.

[19]. Hye, A. M. Q., Malik, S., \& Mashkoor, M. (2010). Government Expenditure, Agricultural Product Prices and Agricultural Growth: A Case of Pakistan.

[20]. Iwai, N., \& Thompson, R. S. (2003). Economic Integration, Production Stability and Economic Growth: The Ohio State University Working Paper: AEDE-WP-0035-03

[21]. Khan, A. E. R., \& Hye, A. M. Q. (n.d.) Agricultural Land Expansion in Pakistan: An Empirical Analysis.

[22]. Lensink, R \& Morrissey, O 2000, 'Foreign Direct Investment: Flows, Volatility, and the Impact on Growth,' Review of International Economics, Vol. 1, pp 478-493

[23]. Matsuyama (1996). Agricultural Productivity and Economic Growth: Empirical Analysis is on the Contemporary Developing Countries.

[24]. McNellis PE (2009). Foreign investment in developing country agriculture - the emerging role of private sector finance. FAO Commodity and Trade Policy Research Working Paper No. 28.

[25]. Meijerink, G., \& Roze, P. (2007). The role of agriculture in economic development: Markets, Chains and Sustainable Development Strategy \& Policy paper 4

[26]. McNellis PE (2009). Foreign investment in developing country agriculture - the emerging role of private sector finance. FAO Commodity and Trade Policy Research Working Paper No. 28

[27]. Miller C, Richter S, McNellis PE, Mhlanga N (2010). Agricultural investment funds for developing countries,FAO, Rome.

[28]. OECD-FAO (2011). Agricultural Outlook 2011-2020.OECD, Paris, FAO, Rome Pesaran, MH, Renelt, Y \& Smith, R 2001, 'Bounds testing approaches to the analysis of level relationships,' Journal of Applied Econometrics, Vol. 16, pp 289-326

[29]. Taylor, SJ 1986, 'Modelling Volatility in Time Series data,' New York, Wiley UNCTAD (2009). World Investment Report 2009. Geneva, Switzerland

[30]. Waqar Akram, Zakir Hussain, Hazoor M. Sabir and Ijaz Hussain (2008) - Impact of agriculture credit on growth and poverty in Pakistan. European Journal of Scientific Research ISSN 1450 216X Vol.23 World Bank (2011), Development Index, Retrieved from Data Publications www.econ.worldbank.org 